\title{
A Universidade face aos desafios do futuro
}

\author{
Nuno Rodrigues Grande \\ Pró-reitor da Universidade do Porto
}

https://doi.org/10.5628/rpcd.01.01.05

As transformações aceleradas que caracterizam as grandes mudanças do mundo actual estão a reflectir-se de forma determinante na identidade de todas as instituições humanas. A Universidade, pela natureza da respectiva estrutura e objectivos, sofre as consequências destas transformações, mesmo quando as mudanças são o resultado da actividade universitária.

$\mathrm{O}$ acesso às fontes do conhecimento alarga-se de forma incontrolável com o desenvolvimento das novas tecnologias de ensino e aprendizagem.

Deste modo, as relações entre docentes e alunos estão a modificar-se, sendo que perde importância o saber livresco e ganha o de experiência feito.

Já hoje o docente é mais o orientador crítico do crescimento científico e técnico dos alunos e o educador pelo exemplo e pelas atitudes do que o repetidor de conteúdos existentes nas diversas formas de registo a que os alunos têm fácil acesso e com apresentações pedagógicas altamente imaginativas e testadas.

A Universidade, por isso, terá que ser, mais do que hoje, o local onde se constrói o novo conhecimento científico, que permuta com outras instituições produtoras de ciência, e difunde para a sociedade que o utiliza.

No futuro, a Universidade aumentará o diálogo com outras instituições públicas e privadas com o objectivo de participar no estudo e nas acções relacionadas com o desenvolvimento. Esta relação tornar-se-á um imperativo de sobrevivência das Universidades pois a necessidade de pertinência das acções educativas e de pesquisa ser-lhe-á exigida pelos Estados para que se justifique o custo crescente da respectiva existência. A Universidade terá que, no futuro, manter mecanismos de educação permanente e contínua dos profissionais que vier a licenciar pois não pode alhearse da evolução dos conhecimentos científicos e técnicos que se faz a uma crescente velocidade. Participará, por isso, na reciclagem dos técnicos que desenvolvem actividades nas diversas empresas e instituições, por iniciativa própria ou como resposta às solicitações externas.

A globalização da difusão do conhecimento imporá às Universidades a necessidade de se articularem em rede de forma a estabelecerem-se processos de constante interajuda e de potencialização recíproca.

A possibilidade de utilizar meios de computação para realizar ensino não presencial, irá permitir a criação da chamada Universidade Virtual, processo de se atingir grandes massas populacionais, permitir a auto aprendizagem segundo ritmos diferentes e permutar programas e projectos entre Escolas com objectivos institucionais e educacionais semelhantes de Universidades situadas em diversas latitudes. A Universidade responderá ao desafio do futuro tornando-se cada vez mais universal e participante, o que dará novo sentido à responsabilidade dos docentes e outro significado à condição de ser aluno.

A importância da Universidade nos futuros arranjos político-sociais aumentará se for possível alterar a rigidez e o anacronismo de alguns dos processos organizativos que a estruturam nos nossos dias. Se não for, perderá impacto e será automaticamente marginalizada e deixará de intervir no projecto colectivo dos povos a que pertencer.

Tenho esperança que, no caso português, a geração que começou já a preparar o futuro tenha o inconformismo, a lucidez e a coragem para que a Universidade promova a mudança sem perder a identidade. 